\title{
Better the "Level" You Know: Translating Arabic Diglossia in Literature
}

\author{
Dr. Sameh Salah M. A. Youssef \\ Department of English Language \& Literature \\ Faculty of Arts, Helwan University
}




\section{Introduction:}

This paper is about problems of translating different language levels within a framework of codeswitching in diglossic situations in modern Arabic literature. Arabic is a diglossic language, and in modern Arabic literature it could be triglossic. However, most Arabic writers tend to write in Modern Standard Arabic, while they shift to different language levels in dialogue situations in their artworks. The diglossic situation is complicated when Arabic literary works display standard Arabic, a high variety, standard colloquial or informal, another high variety, and regional colloquial varieties, low varieties. Such diglossic situations occur as writers switch codes and use different language levels for a purpose. Accordingly, translators usually face this dilemma, especially when they attempt texts from languages high in diglossia, like Arabic, into languages less diglossic, like English.

This paper shall attempt a few questions such as: Why do writers tend to switch codes? By proxy, should translators follow suit, and why? How can translators face the challenge of translating different language levels in an artwork? Is it appropriate to compensate loss in a source text effect by recreating a similar effect 
in the target text? An attempt to find answers to these questions shall follow a quick and brief review of the terms and theories to be employed in this paper.

Language is context-sensitive, and this sensitivity falls into the domain of sociolinguistics. According to Spolsky (2003: 14), sociolinguistics must go beyond language and bring in social context, as sociolinguistics must deal with the real texts that make up human communication and the social situations in which they are used. Because there are different variations in a given language that correlate with the locality where this language is spoken, such variations may take several forms ranging from syntactic and phonological characteristics through lexical choices to meaning systems. One may use several terms to denote language variations, such as language levels, registers, vernaculars, slangs, dialects, varieties or codes. Though there are differences between these terms, sometimes narrow, in the context of this paper, the term 'level' shall be widely applied, but it is inevitable to use and sometimes quote, other similar terms. Like many frequently used terms in linguistics, the term 'level' may have several connotations, but it is used in this paper to refer to different social, regional and ethnic varieties of 
language as used in Ghanem's Arabic novel 'The Man Who Lost His Shadow' (1988 [1962]), its English translation and the suggested translation in the analysis section. Because translating different levels of language in a text is a devil that challenges translators, the term 'level' is used to suggest the difficulty of the translating process as it replaces the word 'devil' in the English proverb 'Better the devil you know than the devil you don't,' and give a hint to suggested solutions for this translation challenge as discussed in the analysis.

Arabic is rich with different levels of language, making it a highly diglossic language. In Arabic literature, authors usually resort to the standard variety of Arabic at the expense of other varieties, which are usually seen as inferior. However, some modern Arabic literature writers have the courage to write dialogues in their literary works in slangs, reflecting several features like power, prestige and social class, among others. Because the history of diglossia has been told and retold, it shall be dealt with here briefly. Diglossia appeared in the works of the German Linguist Karl Krumbacher in 1902, then Ferguson reintroduced diglossia, stating that it is a relatively stable language situation in which, in addition to the 
primary dialects of the language, there is a very divergent, highly codified superposed variety, the vehicle of a large and respected body of written literature.

For convenience of reference, this study shall apply the proposed hypothesis of Ferguson that ' $\mathrm{H}$ ' refers to the standard or high level/variety of language, whereas ' $L$ ' refers to the regional or low level/variety. As stated earlier, most literary works in Arabic are usually written in $\mathbf{H}$, dialogues are in standard colloquial, which is seen as an $\mathbf{H}$, and some dialogues feature regional varieties, seen as an L. As a result, some Arabic literary works can be written in three levels/varieties. Though writing in both $H$ and $L$ gives the literary work a sense of friendliness with the reader, it poses a great challenge to translators, especially if they translate to a language less diglossic than Arabic. In addition to the challenge of rendering an equivalent level of language, one of the problems translators face is determining the specific social connotations of the $L$ variety. This recalls Bakhtin's notion of heteroglossia, which describes the coexistence of distinct varieties within a single language. Bakhtin defines heteroglossia as: 
The internal stratification of any single national language into social dialects, characteristic group behavior, professional jargons, generic languages, languages of generations and age groups, tendentious languages, languages of the authorities, of various circles and of passing fashions, languages that serve the specific sociopolitical purposes of the day, even of the hour (each day has its own slogan, its own vocabulary, its own emphases) - this internal stratification [is] present in every language at any given moment of its historical existence. (1981 [1935]:262)

Diglossic situations in literary works are usually accompanied by code-switching. Alvarez-Cáccamo (1999: 29) maintains that code-switching falls primarily between two camps, the first sees that the use of recognizably distinct speech varieties in discourse may have accountable meanings and effects, and thus speech varieties have been mechanistically associated with 'codes', whereas the second camp sees that if codes do not contrast, they are not distinct codes, and thus associate code-switching to bilingualism. Though the two camps have points to consider, this paper is not in a position of defending or criticizing any of the two perspectives, but rather, and for the purposes of this 
study, it adopts the view that moving between different levels of the same language is a switch of code as what matters in this paper is to spot the functions of switching and duly check on how they are translated, or should be translated. While the study of code-switching focuses traditionally on the issue of language choices in different situations, more recent studies, according to Auer (1995), tackle code-switching as a communicative vehicle carrying certain meanings and inferences.

In the diglossic modern Arabic literature, codeswitching is clear; yet when discussing this linguistic phenomenon, one will make clear distinction between code-switching in the novel, and code switching in the language of the characters. This aims at the proper understanding of the functions and effects of the switch. Code-switching in the novel is evident when the writer changes the level of standard Arabic as the predominant narration language of the novel to the language of dialogues between the characters; meanwhile, code-switching by the characters in the novel, from an $\mathrm{H}$ to $\mathrm{L}$ for example, has significance and carries messages and functions that should be wellunderstood. Spolsky (2003: 50) maintains that codeswitching is associated with topics, places, and identities 
along with the roles associated with them; codeswitching signals that speakers are members of the same ethnic group, which is anchored to the issue of identity as this mechanism signals social attitude and demonstrates group membership and solidarity. The selection of a language level, thus, carries a considerable social meaning that should be understood properly to create an equivalent translation.

In Fathy Ghanem's 'The Man Who Lost His Shadow', there are three predominant varieties making up the linguistic repertoire, namely: Modern standard Arabic used by the writer and/or narrator of each of the four books, the higher (Cairene) vernacular, used by most of the characters in the novel, and the lower (countryside) vernacular, used by Mabruka upon her arrival to Cairo, her mother and Sheikh Dessouky. Arabic readers would recognize from the first instance that the language level used by the three characters in Book One 'Mabruka' is a regional lower variety, especially when compared to the standard variety of all other characters. The uniqueness of 'The Man Who Lost His Shadow' is that this 4-book novel recounts the story of Yusif Abdul Hamid, an ambitious journalist, from four perspectives. The writer skillfully uses the 
three levels as discourse markers to send messages to the reader about social status, prestige, power, and solidarity among others. In this connection, Spolsky (2003: 25) maintains that it is important to relate the significant language varieties to the significant social groups and situations. These levels, and the messages sent, should be rendered equivalently and invisibly into English in the process of translating. Stadlbauer (2010) maintains that language ideologies are never about language alone, but rather, envision and enact ties of language to identity, to aesthetics, to morality and to epistemology. She adds that dialectical relations often determine which linguistic features get selected for cultural attention and for social marking. Therefore, language choices in a text should be honestly mirrored in the translation. Language choices in the Arabic novel text are reflective of identity, especially in the $L$ level as appeared in dialogues. While Bell (2007:107-108) maintains that a dialogue is the basic instantiation of language, which regards the addressee as being as important as the speaker, placing style at the center of linguistic variety, translation should reflect these features. In relation to this, Benjamin (1969: 70-71) maintains that translation is a mode, stressing that the 
task of the translator must be finding the intended effect in the source text, and duly the translator should translate it as an echo of the original. For that reason, this paper is concerned with exploring the essential features leading to the equivalent rendering of meaning of different language levels in modern Arabic literature so as to echo the original.

To answer the question about reasons that writers tend to switch codes, Hess (1996: 6) argues that codeswitching in literary texts, where writing often becomes speech on paper, is a neglected field worthy of further investigation, adding that in literature, languages are not switched because of authorial bilingualism but rather to fulfill artistic and literary functions. Omole (1987) discusses several functions for code-switching in literature, proposing that it is useful for cultural references, in-group appeal, the addition of 'spice' through lexis, which is untranslatable, the hint for local color, and for the social stratification of characters. Blom and Gumperz (1972) maintain that language choices are situation-based and governed by social norms, which they called situational code-switching; hence, they add that code-switching has a significant social function, arguing that the local dialect, i.e., the $L$ 
variety, serves to flag local culture and identity while it is used in familial and friendship interactions, whereas using the standard or the $\mathrm{H}$ variety serves to flag speech acts that include outsiders and formal situations. Further, Hess (1996: 17) argues that code switching and style shifting in several literary works underline central themes of alienation, transition and liminality.

While writers in modern Arabic literature tend to use dialects in dialogues to cast a touch of realism, they switch code to the Standard variety when they narrate. Translation studies, however, tackled, to some extent, the issue of translating dialects, but there is not enough attention paid for the techniques of translating different language levels as they occur within diglossia and codeswitching.

Lambert (2001: 130) says that the main problems of literary translation through the ages are the difficulty of translating well and being faithful, which is based on an assumption of universality; meanwhile, Bush (2001: 127) argues that a literary translator is bilingual and bicultural and thus inhabits a landscape which is not mapped by conventional geographies. Thus, it is the status of bilingualism and biculturalism that allows the competent translator to decide which adjustments 
should be made; such adjustments should not be prescriptive, but rather descriptive, according to the language pairs and situation. As put by Dollerup (2004: 145), translation practice and translation theory are not always - some might indeed say 'never' - good bedfellows, as practical translation is tied to concrete contexts and situations, whereas abstract thinking usually moves in loftier realms.

According to Nida (1964), different approaches to translations are due to three basic factors: 1 ) the nature of the message, 2) the purpose of the author, and by proxy, the translator, and 3) the type of audience. Youssef (2005: 50) maintains that the translation situation determines the set of translation strategies to be used. For example, a translator may focus on the source text in the socio-cultural settings, thus placing certain social concerns (like gender, class, etc) above other concerns (like acceptability, readability, informativity, etc), while another translator may focus on the stylistic or syntactic concerns. So, the use of the technique is situation dependent. In addition, Venuti (2001: 243-44) says that strategies of translation could be domesticating or foreignizing strategies, depending on a detailed reconstruction of the cultural formation in 
which the translation is produced and consumed. Further, he adds that foreignizing strategies have been implemented in literary, as opposed to technical, translation, which is fundamentally domesticating, maintaining that a literary translator can experiment in the choice of foreign texts and in the development of translation methods, constrained primarily by the current situation in the target-language culture.

Discussing the functional and communicative approaches, Mason (2001: 29-30) says that several translation theorists have tackled the communicative events and the analysis of varieties in language and have applied such notions to the study of translation, and duly register analysis came to be seen as a powerful tool in the analysis of texts, and therefore in translation, as the establishment of equivalence on the language level is the major factor in the process of translation. Mason maintains that adjustments have to be made when translating different language varieties and registers in different linguistic and cultural settings. In the framework of translating dialects, Newmark (1981) argues that translation suffers some loss of meaning in some cases including poetry, texts with wordplay or cultural content and dialect. Though this paper is not in 
a position of criticizing or defending Newmark's argument, there are several solutions to this problem including finding dynamic equivalence, rather than formal equivalence, as the analysis shall clarify. Catford (1974) and Venuti (1995) maintain that complete equivalence is an illusion as languages differ and the shift from one language to another means altering the form, while contrasting forms convey meanings, a matter that cannot but fail to coincide totally. Anderman (2001: 71-73) says about translating dialects that the translator will have to make a decision as to whether there is a suitable dialect in the target language into which it may be translated. She maintains that due to the fact that English is one of the most widely spoken languages in the world, translators of literary works into English resort to a greater degree of adjustment in their translation because of the unfamiliarity of English audiences with source language cultures and societies.

This paper discusses the adjustments made, or rather should be made, by translators and how to make decisions when translating different language levels in dialogues in modern Arabic literature. In this connection, Dubois (1994 [1973]: 486) says that translation is the expression in another language 
(Target Language) of what has been expressed in another (Source Language), preserving semantic and stylistic equivalence. This decades-old definition can be slightly altered to read: translation is the expression in another language (Target Language) of what has been expressed in another (Source Language), preserving semantic, stylistic and pragmatic equivalence. The need of a pragmatic dimension in translation becomes a must as pragmatics is concerned with the functions and use of language. As the study of translation has been dominated by the debate whether it is a science or an art, linguists approach translation as a science, yet it is still argued that translation is an art or craft and therefore not amenable to objective scientific explanations. One of the aims of this paper is to accommodate practice of translation into theory of translation.

To sum up, this quick and brief review of several translation theories suggests that although literary translators are bilingual and bicultural, the main problem of translating literature is translating well and being faithful. It is argued that complete equivalence is an illusion, and some translation instances may entail loss. Practical translation is different from abstract 
thinking, and duly a translation situation determines the strategies to be followed, as the technique used is situation dependent, while translation strategies could be domesticating or foreignizing. Texts are culturallysensitive and thus register analysis is important for text analysis and translation, which needs the translator to make a decision to select the appropriate dialect in the target language into which such texts may be translated. Translators need also to make adjustments when translating different language varieties in different linguistic and cultural settings. The dilemma of translating different language levels shall be discussed in the analysis section below.

\section{Analysis:}

Readers of the Arabic version of Fathi Ghanem's 'The Man Who Lost His Shadow' and its English translation would observe that:

1- Levels of language used in the Arabic version of the novel fluctuate sharply between:

a. The voice of the narrator is written in Modern Standard Arabic (H),

b. Dialogues are written either in a high colloquial variety $(H)$ or a low colloquial variety (L). 
2- Levels of language used in the English version of the novel do not reflect similar sharp fluctuations:

a. The voice of the narrator is written in Standard English (H),

b. Dialogues are written in a high colloquial variety $(\mathbf{H})$.

3- The most obvious violations of the translation of language levels are in part one 'Mabruka'.

In the discussion below, though the translation of different language levels shall be discussed, sometimes it would be inevitable to comment on some points in translation irrelevant to language levels.

Example one:

The poor village woman, Nafisa, and her 10-yearold daughter Mabruka, escorted by an old man from their village, Sheikh Dessouky, go to Cairo so that Mabruka would work as a servant for a rich family. Mabruka, the narrator of the first book, describes her first train trip, the vast world she sees for the first time, and the big city. When they reached a big house with a garden, a black man in a big turban was at the gate. The following dialogue takes place: 


$$
\begin{aligned}
& \text { - راتب بيه موجود يا عم عثمان؟ } \\
& \text { فأجابه وهو ينقل عينيه بيني وبين أمي: } \\
& \text { - البيه خرج ولسه ما جاش.. } \\
& \text { وعاد الشيخ دسوقي يسأله: } \\
& \text { - و والست الكبيزة؟ } \\
& \text { - موجودة - مود } \\
& \text { - طيب أدخل أسلم عليها.. }
\end{aligned}
$$

(...) ولاحظت أن عم عثمان يطيل النظر إلينا، ثم قال فجأة: - ما تقعدوش قدام الباب.. خشوا جوه؟؟

$$
\text { - نجعد جوه له أمي: }
$$

أفر متهل (... ثم ظهر الشيخ دسوقي خارجاً من الباب الضيق، وما كاد يرانا حتى أقبل على أمي متهلل الوجه وقال لها:

- الست الكبيرة رضيت يا نفيسة.. لو عجبتها ح تدفع ثمانين جرش

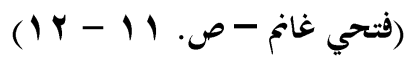

The English text reads:

(...) and Sheikh Dessouki asked him:

'Is Rateb Bey at home, Uncle Osman?'

The man's eyes moved between me and my mother:

The Bey's gone out and not come back.'

'And the old lady?'

'At home.'

'I'll call on her, then' 
(...) He stared at us a moment then said:

'Don't sit in front of the gate. Go and sit inside.' 'Inside where?'

(...) Then Sheikh Dessouki came out of the little door, beaming.

'The old lady agrees, Layla. If she proves good, she'll get sixteen shillings.'

(Stewart, D., pp. 10-11)

In the Arabic dialogue, Sheikh Dessouki talks to Osman, the gatekeeper, in a Cairene colloquial variety of Arabic, an $H$ variety, and Osman replies using the same level of language. Any Arabic reader can easily identify that there is a change in the level of language in two instances: 1) In the two-word utterance of Mabruka's mother, when she uses her regional variety of colloquial Arabic (L), and 2) in the utterance of Sheikh Dessouki to Mabruka's mother, when he uses the same regional variety of colloquial Arabic. The writer uses a switch of code between $H$ and $L$ Arabic varieties in this dialogue for several reasons: 1) to give the literary work a sense of reality, as it would be misleading for an Arabic reader to read the mother's talk in a standard Arabic or in Cairene colloquial (H), 2) to portray the inferior social status of the mother and Mabruka, even when compared to the gatekeeper, and 
3) Sheikh Dessouki switches codes to an $L$ variety when he talks to the mother, to show solidarity and ethnic identity with the mother, a view supported by Spolsky (2003: 57), and by Hess (1996: 12) who maintains that speakers change code as appropriate for their audience. Further, in his 1973 book 'Levels of Contemporary Arabic in Egypt', Badawy says that while sentences offer choices which function as indicators of the social provenance of the user (dialect features), they also offer markers of the use to which the language was put (register features). Meanwhile, Schiffman (1998) maintains that in most diglossic languages, the literature is all in $\mathrm{H}$ variety; no written uses of $\mathrm{L}$ exist, except for 'dialect' poetry, advertising, or 'low' restricted genres. In most diglossic languages, the $\mathbf{H}$ variety is thought to be the language; the $L$ variety is sometimes denied to exist, or is claimed to be only spoken by lesser mortals (servants, women, children). These features are not reflected in the English translation, as all the dialogue is translated into the same level of colloquial, without showcasing the regional variety. Duly, the three reasons discussed above for the code switching are not reflected in the English version. One of the solutions is that the 
translator could have translated the $L$ variety of Arabic into a similar $L$ variety in English for a closer rapprochement to the English readers, so that the translation would be invisible. According to Venuti (1995) translation should read fluently in the target text because it lets the translation pass as an original text in the target language. This notion is known as 'invisibility,' which is described by Venuti as a transparent translation, reflecting the foreign writer's personality or intention, without prejudice to the meaning of the text. In other words, the translation is not seen as a translation but the original. Like Fathy Ghanem, English writers switch codes between $\mathrm{H}$ and $\mathrm{L}$ varieties in their literary works to achieve certain objectives. This can be seen in the works of several writers in English, and to give an example, take George Bernard Shaw in 'Pygmalion,' when Eliza Doolittle, the cockney flower girl, is educated at the hands of Henry Higgins, the professor of phonetics. Eliza's language at the outset of the play shows an inferior level of language, similar to what Ghanem writes.

Back to the English translation, the problem is that the functions communicated by the Arabic text are not reflected in the English text. The $L$ in Arabic could be 
translated as an $L$ of British or American English. To suggest a translation, the passage would read as follows, noting that changes are underlined:

He stared at us a moment then said:

'Don't sit in front of the gate. Go and sit inside.'

'Where at?'

(...) Then Sheikh Dessouki came out of the little door, beaming.

'The old lady says it's okay by her, Layla. If she does $\underline{\mathrm{OK}}$, she'll get 16 shillings.'

After using the $L$ variety in the English translation, one may recalculate whether the three functions discussed earlier exist in the English text:

1) The English translation gives the literary work a sense of reality, using different language levels, as one may encounter in real life,

2) Using $L$ portrays an inferior social status, even when compared to the gatekeeper, and

3) When Sheikh Dessouki switches codes when he talks to the mother, it becomes clear that this is a show of solidarity and a share of ethnic identity. Hess (1996: 14) argues that words are used to solidify the in-group experience of a marginalized group so as to heighten and focus their special nature. Though these changes 
would seem small, yet they achieved the functions intended originally in the Arabic text.

Before moving forward to another example, two points need commentary in the translation of this dialogue, though partly irrelevant to the topic of this paper. The first point is the use of Uncle as an addressing form. Sheikh Dessouki is an old man, and probably older than Osman. The context of using the term ' عم in Arabic is situation-dependent; the direct meaning is 'uncle', but the term is widely used as an addressing form to show respect for older people. The translator took the direct lexical meaning of the word and inserted it in the text, which gives an alien feeling for the English reader. A suitable equivalent translation would be 'Mister', which is a conventional title of respect for a man, prefixed to the name.

The second point is the name of Mabruka's mother. In the Arabic text, it is Nafisa, however the translator changes it to Layla in the English version. Throughout the novel, this is the only instance that her name is mentioned. Choosing an English name of an Arabic origin is acceptable in translation, especially the Arabic name does not have any special significance. According to Venuti (1995) translation should read 
fluently in the target text because it lets the translation pass as an original text in the target language, adding that a translated text is judged acceptable by readers when it reads fluently without any linguistic or stylistic peculiarity that would give the text a foreign taste. Youssef (2005: 100) maintains that during the translation process, the translator, sometimes, finds himself between two options: Finding formal equivalents to preserve the context-free semantics of the text at the expense of its context-sensitive communicative value, or finding functional equivalents to preserve context-sensitive communicative value at the expense of its context-free semantics. The translator in this situation goes for functional equivalents to preserve the context-sensitive communicative value.

Example two:

In this example, Layla/Nafisah, accompanied by Sheikh Dessouki and Mabruka, went for the interview. When the old lady meets them, Layla/Nafisah kissed her hand and prayed God for her, and the girl passed the interview successfully. This diglossic Arabic dialogue features several language levels. The Arabic text reads: 
وغطت أمي يدها بطرحتها السوداء وصافحت السيدة وانخنت على يدها تقبلها وهي



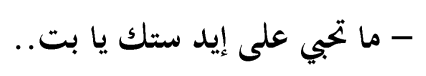
فتبلت يدها التي سحبتها بسرعة قبل أن تلمسها شفتاي ، وسألتني بصوت ضعيف - السمك إيه يا شاطرة؟ - - -

$$
\text { - - جوأي للست أمي تلكزلي في كتفي: }
$$

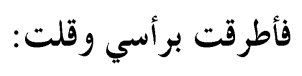



$$
\text { ولكزتني أمي من جديد و كأي ارتكبت جرماً كبيراً وقالت: }
$$

- خدامتك مبرو كة.. و وكلنا خدامينك يا ست، وطول عمرنا عايشين بنفسك ونفس البيه

$$
\text { الكبير. }
$$

وانطلقت أمي في دعواتا للسيدة العجوز التي التفتت إلى الشيخ دسوقي وقالت له بصوقا الضعيف: وانط: أني - خحلاص اتفقنا يا شيخ دسوقي.

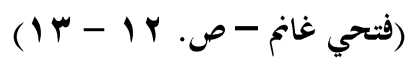

The English text reads:

My mother covered her hand with her black headcover, before stooping to kiss the lady's hand, praying God to grant her long years and lasting bounty. Turning, she prodded my shoulder:

'Kiss your mistress's hand, child,'

The old lady withdrew her hand before my lips touched it. 
'What's your name, girl?' Her voice was feeble.

My mother quickly nudged me:

'Tell the lady your name.'

I lowered my head.

'My name's Mabruka.'

Mother, nudging me once more as if I had done something really bad, corrected me

'Your servant Mabruka. We are all your servants, Madame. We live thanks to your breath and the breath of the great Bey.'

Mother then began praying for the old lady, who said to Sheikh Dessouki in her faint voice:

'Enough - we have agreed.'

(Stewart, D., pp. 11-12)

The Arabic dialogue features a humble attitude on the part of Layla/Nafisah, associated with an $L$ level of language, giving the Arabic reader a sense of degradation and poverty, especially when compared to the language of the old lady, who speaks briefly and in an $\mathrm{H}$ level of language; however, her talk reflects power and prestige as depicted in words like (يا شاطرة - خلاص). When the lady asked Mabruka about her name, the mother quickly interfered with a nudge to correct Mabruka, which adds more derogation with words like (خدامتك). When the old lady wants to conclude the interview, she talks to Sheikh Dessouki, not the mother, 
in another show of prestige and power. Certain lexical choices in the talk of Layla/Nafisah have cultural significance: When she asks Mabruka ( ما تحبي على إيد ستتك ), which means (kiss your mistress's hand), she talks in an L level of Egyptian Arabic, using a derogatory word for kissing the hands and/or heads. Spolsky (2003: 20) maintains that the most common kinds of politeness formulas are involved with greetings, which are the basic oil of social relations, adding that each social group has its own set of rules about what is an appropriate form of greeting. Giving an example, Spolsky says that Arab greetings use an elaborate set of paired greetings-plus responses, depending on time of day or other social aspects of the situation. There is also another phonological feature in Layla/Nafisa's utterances that signifies her regional dialect and ethnic identity, as she pronounces the letter (ق) as (ج), as reflected in the Arabic written text.

The English translation misses several features of the Arabic text. Whereas the English text presents features of humble attitude from Layla/Nafisah as portrayed from her use of words like (kiss the hand, your servant, etc.), this is not reflected in the level of language used. So, the function of degradation is fully 
realized in the Arabic text, and partly in the English text. The translator could have added a word or phrase to compensate for this shortage, due to the absence of an English equivalent to the word (حبي) or (kiss). The translation could read: 'bow and kiss your mistress's hand' to show degradation and modesty before the old lady, as the Arabic text suggests.

The distance between the levels used by interlocuters must be maintained, either by lowering the level of one or raising the level of the other. In such a situation, the translator could have compensated the gap by using the 'posh' in English. According to Harvey (2001: 37), compensation is a technique which involves making up for the loss of a source text effect by recreating a similar effect in the target text through means that are specific to the target language and/or text.

In the Arabic dialogue, the mother used to call Mabruka (يا بت), which is an L level, a colloquial Arabic derivation of the standard word (بنت). Because the word (شاطرة) is translated as (girl), it is suggested that the when Layla/Nafisah calls Mabruka, she would use the colloquial English word (gal) so that the English reader would easily identify the change of the language level. 
However, if the translator is keen to maintain the gap between the two language levels, he could have compensated the phonological cues for ethnic identity with a twisted structure of some utterances of Layla/Nafisah to match, for example, the $L$ level of language. If equivalence cannot be achieved, for technical reasons, on the phonological level, compensation on other levels would be welcomed. Nevertheless, if the utterance in the Arabic dialogue cannot be translated into a similar level in the target language for whatever linguistic/cultural reason, the addition of a simple phrase like (she said in her country accent) is suggested to clarify the difference between the levels. If equivalence cannot be achieved, it would be a denial of the power of language and the infinite novelty of expression.

Consider the following changes in the dialogue:

- 'Bow and Kiss your mistress's hand, gal,' instead of 'Kiss your mistress's hand, child,'

- 'Tell the lady what your name is.' instead of 'Tell the lady your name.'

- 'I'm called Mabruka.' instead of 'My name's Mabruka.'

- 'That ain't no way to talk. Tell her, your servant Mabruka. We're all your servants, Ma'am.' instead of 
'Your servant Mabruka. We are all your servants, Madame.'

Again, one may recalculate whether the functions, generated by the Arabic text, exist in the English text: 1) The English translation reflects a humble attitude from the part of Layla/Nafisah, associated with an L level of language, giving the English reader a sense of degradation and poverty, 2) using the word (gal) clarifies the difference between the two language levels, and 3) using twisted structure of English compensates for the phonological twist in the Arabic text, and therefore the function of the text is realized.

Though there are several points to comment on in the translation of this dialogue, the most obvious point is the literal translation of the idiom ( عايثين بنفسك ونفس (البيه الكبير), which is translated as (We live thanks to your breath and the breath of the great Bey). The English sentence is meaningless, as the actual meaning is (Without you, we wouldn't live) or (We're much obliged for your generosity).

\section{Conclusion}

This paper focuses on the means to translate different levels of language in Arabic literature within a framework of code-switching, a devil that challenges 
translators. Different language levels pose serious challenges as they convey several messages, ranging from showcasing power and solidarity to signaling ethnic identity. The paper takes on Fathy Ghanem's novel 'The Man Who Lost His Shadow' and its English translation, as the novel portrays, especially in part one, book one: 'Mabruka', a huge gap between the levels of language spoken by the characters, ranging from $\mathrm{H}$ of Modern Standard Arabic, through $\mathrm{H}$ of spoken colloquial Egyptian Arabic and $L$ of a regional dialect. It is observed that dialogues in the English translation are translated in informal/standard colloquial English $(\mathrm{H})$, regardless of the language level in the Arabic text, which results in ignoring several semiotic and sociolinguistic features, such as power, solidarity, social status, ethnic identity and geographic region, among others. Although dialogues carry information, meanings are conveyed as part of the interactive process, which are not reflected in the English translation, and thus equivalence is not achieved.

In the analysis, several translation techniques are discussed and alternative translations of dialogues are suggested. These techniques include: 
1. The $L$ variety in Arabic could be translated as an $L$ variety of British or American English for a closer rapprochement to the English readers,

2. When a term is absent in the target language, the translator may add a word or phrase to compensate for this shortage,

3. The use of twisted structure in the target language compensates for the phonological twist in the source language to realize the functions of the text,

4. Compensation for loss of a source text effect could be made by recreating a similar effect in the target text through means that are specific to the target language because if equivalence cannot be achieved, it would be a denial of the power of language and the infinite novelty of expression, and

5. The distance between the levels used by interlocuters must be maintained, either by lowering the level of one or raising the level of the other.

Finally, the topic of the paper is well worth further critical investigation and academic analysis.

IV. Limitations and further research:

The findings of this paper should be cautiously interpreted for more as it discusses one genre of an $\mathrm{L}$ variety, and the study is applied to the highly diglossic 
Arabic language, and duly further research on the topic is encouraged between other language pairs. 


\section{References}

Alvarez-Cáccamo, C. 1999. 'From switching code to code-switching: Towards a reconceptualisation of communicative codes' in Auer, P. (Editor), CodeSwitching in Conversation: Language, Interaction and Identity, London: Routledge, pp. 29-50.

Anderman, G. 2001. 'Drama Translation' in Baker, M. (Editor), Routledge Encyclopedia of Translation Studies, London: Routledge, pp 71-74

Auer, P. 1995. 'The pragmatics of code-switching: A sequential approach,' in Milroy, L \& Muysken, $P$. (Eds.), One speaker, two languages: cross-disciplinary perspectives, Cambridge: Cambridge University Press, pp. 115- 35.

Badawy, S. 1973. Mostawayat al-'Arabiya alMu'asera fi Misr (in Arabic). Cairo: Dar al-Ma'aref.

Bakhtin, M. 1981 [1935]. 'Discourse in the novel', in M. Holquist, M. (ed) Emerson, C. and Holquist, M. (trans.) The dialogic imagination. Austin: University of Texas Press, pp. 259-422.

Bell, A. 2007. 'Style in dialogue: Bakhtin and sociolinguistic theory' in Bayley, R, and Lucas C. (eds.) Sociolinguistic Variation: Theories, Methods, and 
Applications, New York: Cambridge University Press, pp. 90-109.

Benjamin, W. 1969. Illuminations, New York: Schoken Books.

Blom, P. and Gumperz, H. 1972. 'Social meaning in linguistic structures: Code-switching in Norway', in J. Gumperz and D. Hymes (eds) Directions in Sociolinguistics: The Ethnography of Speaking, New York: Holt, Rinehart and Winston, pp. 409-35

Bush, P. 2001. Literary translation practices' in Baker, M. (Editor), Routledge Encyclopedia of Translation Studies, London: Routledge, pp. 127-30

Catford, C. 1974 [1965]. A Linguistic Theory of Translation, New York: Oxford University Press.

Dollerup, C. 2004. 'The authoritativeness of translations' in Across Languages and Cultures, Vol. 5 (2), Budapest: Akadémiai Kiadó, pp. 145-157.

Dubois, J. et al., 1994 [1973]. Dictionnaire de Linguistique, Paris: Larousse.

Ferguson, C. 1959. 'Diglossia', in Word, vol. 15, pp. 325-40. 
Ghanem, F. 1988 [1962]. Al-Rajul alladhi faqada zilluh (in Arabic), Cairo: Rose Alyoussef

Ghanem, F. 1994 [1966]. The Man Who Lost His Shadow, translated by Stewart, D., Cairo: The American University in Cairo Press.

Harvey, K. 2001. 'Compensation' in Baker, M. (Editor), Routledge Encyclopedia of Translation Studies, London: Routledge, pp. 37-40

Hess, N. 1996. 'Code switching and style shifting as markers of liminality in literature' in Language and Literature, vol. 5 (1), London: Sage Publications, pp. 518.

Lambert, J. 2001. 'Literary translation: research issues' in Baker, M. (Editor), Routledge Encyclopedia of Translation Studies, London: Routledge, pp. 130-33

Mason, I. 2001. Communicative/Functional Approaches' in Baker, M. (Editor), Routledge Encyclopedia of Translation Studies, London: Routledge, pp. 29-33

Newmark, P. 1981. Approaches to Translation, Oxford: Pergamon. 
Nida, E. 1964. Toward a Science of Translating with Special Reference to Principles and Procedures involved in Bible Translation, Leiden: E.J. Brill.

Omole, J. 1987. 'Code-switching in Soyinka's The Interpreters' in Language and Style, vol. 20 (4), WHERE: pp. 385-95.

Schiffman, H. (1998). 'Diglossia as a Sociolinguistic Situation', in Coulmas, F. (Editor), The Handbook of Sociolinguistics, Blackwell Publishing, http://www.blackwellreference.com/public/book.html?i $\underline{d=g 9780631211938 \_9780631211938} \quad$ (accessed 20 February 2013)

Spolsky, B. 2003 [1998]. Sociolinguistics, New York: Oxford University Press.

Stadlbauer, S. 2010. 'Language ideologies in the Arabic diglossia of Egypt' in Colorado Research in Linguistics, Vol. 22. Boulder: University of Colorado, http://www.colorado.edu/ling/CRIL/Volume22_Issue1/p aper_STADLBAUER.pdf (accessed 25 February 2013).

Venuti, L. 1995. The Translator's Invisibility, London: Routledge 
---2 2001. Strategies of translation' in Baker, $M$. (Editor), Routledge Encyclopedia of Translation Studies, London: Routledge, pp. 240-44

Youssef, S. 2005. A Socio-Pragmatic Evaluation of the English Translation of Culturally-Bound Expressions in "Midaq Alley" and "The Sinners", unpublished PhD dissertation, Cairo, Helwan University. 